\title{
Basel Capital Channel and Lending Behavior of Banking Institutions in Nigeria: An
} Empirical Investigation

\author{
Dumini Solomon Igbanibo
}

Department of Banking and Finance Rivers State University, Port Harcourt, Nigeria. Email:igbanibos@yahoo.com

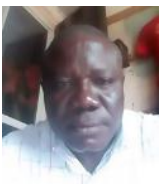

\begin{abstract}
This study is on the role of bank capital on bank lending behavior and other macroeconomic variables. This study examined empirically Basel I Capital (Tier $1+$ Tier 2), Basel II Capital (Total capital requirement), Basel III Capital (Conservation Buffer (CSB) + Counter-Cyclical Buffer (CCB)) and lending behavior of banking institutions in Nigeria. This study is time series in nature and data relating to the study were obtained from Nigerian stock exchange fact sheet and CBN statistical bulletin for the period 1986 through 2019. The analyses of the data were done using descriptive statistical tools and econometric technique of Autoregressive Distributed Lag (ardl), and granger causality test. The results indicate that there is a positive and significant relationship between Basel capital and lending behavior of banking institutions in Nigeria. Also the results show that there is a bi-directional causality between Basel capital and lending behavior in Nigeria. As such we conclude that Basel capital influences growth in credit to the private sector (CPS) and growth in credit to small and medium enterprises (SMEs) in Nigeria.
\end{abstract}

Keywords: Basel I, Basel II, Basel III, Conservation buffer, Counter-Cyclical buffer, Capital channel, Lending behavior, Banking. JEL Classification: E44, E61, G21, G28, E51.

Citation | Dumini Solomon Igbanibo (2020). Basel Capital Channel and Lending Behavior of Banking Institutions in Nigeria: An Empirical investigation. Asian Journal of Social Sciences and Management Studies, 7(2): 124-134.

History:

Received: 14. February 2020

Revised: 26 March 2020

Accepted: 30 April 2020

Published: 21 May 2020

Licensed: This work is licensed under a Creative Commons

Attribution 3.0 License (oc)

Publisher: Asian Online Journal Publishing Group
Funding: This study received no specific financial support.

Competing Interests: The author declares that there are no conflicts of interests regarding the publication of this paper.

Transparency: The author confirms that the manuscript is an honest, accurate, and transparent account of the study was reported; that no vital features of the study have been omitted; and that any discrepancies from the study as planned have been explained.

study as planned have been explained.
This study follows all ethical practices during writing.

\section{Contents}

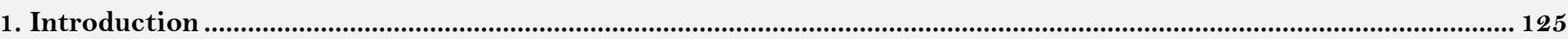

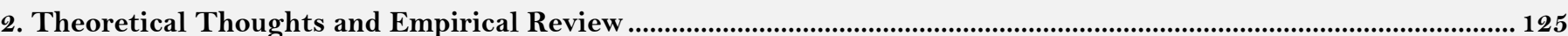

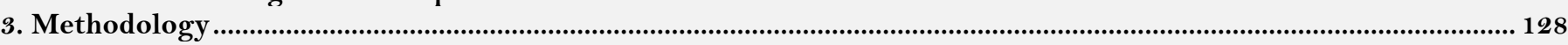

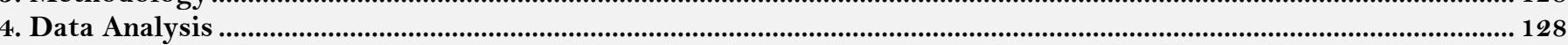

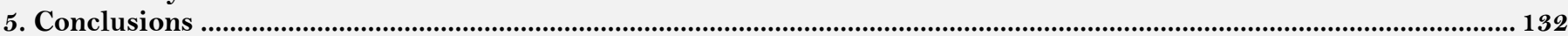

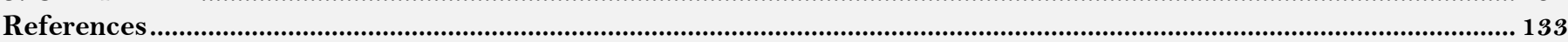




\section{Contribution of this paper to the literature}

This study contributes to existing literature by examining empirically Basel I Capital (Tier 1 + Tier 2), Basel II Capital (Total capital requirement), Basel III Capital (Conservation Buffer (CSB) + Counter-

Cyclical Buffer (CCB)) and lending behavior of banking institutions in Nigeria.

\section{Introduction}

There has been the debate in literature with respect to the role of bank capital on bank lending behavior. The traditional monetary school believes that bank reserves play critical role in determining the volume of bank lending in particular while the bank lending channel thesis maintain that monetary policy actions can largely alter the supply of bank loans by changing bank reserves. According to Diamond and Rajan (2000) higher capital requirement reduces liquidity creation but enables the bank to avoid financial distress and survive more often. Admati, DeMarzo, Hellwig, and Pfleiderer (2010) suggest that better capitalized banks suffer fewer distortions arising from lending and perform well. The study of Barth, Caprio, and Levine (2006) stated that capital regulations do not necessarily exert positive impact on banking system stability. Conversely, Modigliani-Miller theorem argues that given the perfect capital market where there is the absence of taxes and bankruptcy costs, the capital structure of the firm does not matter in deciding the value of the firm. This thought, in banking context, opines that a bank's lending decision is irrelevant to its financial structure if there is a perfect capital market. When a banker does not face any difficulty in lending owing to the presence of the perfect capital market, neither the lending channel nor the capital channel are relevant for the transmission mechanism of monetary policy (Bernanke \& Blinder, 1988). The general understanding is that banks with sound financial health possess higher level of capital and could contribute meaningfully to the financial intermediation.

In the light of the above, several studies in developed economies have established that there is a link between bank capital and bank lending, such that bank capital acts as an automatic amplifier for macroeconomic activities. This amplification of the economy works through the mechanism of the bank capital channel (Albertazzi \& Marchetti, 2010; Blum \& Hellwig, 1995; Blum., 1999; Brun, Fraisse, \& Thesmar, 2013; Buch \& Prieto, 2014; Kapan \& Minoiu, 2013; Van den Heuvel, 2007; Woo, 2003). This is why Van den Heuvel (2007) stated that insufficient bank capital shows how monetary policy affects bank lending behavior. Lending by banks with low capital has a delayed and then amplified reaction to interest rate shocks, relative to well capitalized banks. However, a cursory look at the Nigerian economy shows that not much study has been done to empirically investigate the effects of Basel capital channel on bank lending behavior in considering the uncertain nature of the macroeconomic and financial environment occasioned by macroeconomic fluctuations, incessant bank failure and inability of bank capital to absorb emerging shocks. Hence the research gap this study seeks to fill.

\section{Theoretical Thoughts and Empirical Review \\ 2.1. Theory of Bank Capital Channel}

This theory postulate that monetary policy actions influence bank lending behavior, through its impact on bank equity capital. These monetary policy actions can lead to a change in the financial position of the banking sector, thereby changing the preferences of its shareholder (Markovic, 2006). When bank equity capital is sufficiently low, because of loan losses or some other adverse shocks, the bank will reduce lending because of the capital requirement and the cost of issuing new equity. Even when the capital requirement is not currently binding, the model shows that a low capitalized bank may optimally forgo profitable lending opportunities now to lower the risk of future capital inadequacy. Furthermore, the theory reports that there exist at least two distinct ways in which the level of bank capital may alter the impact of monetary shocks on bank lending and these are through the traditional bank lending channel and the direct mechanism that is known as bank capital channel.

\subsection{Modigliani-Miller Irrelevance Theory}

Modigliani-Miller argued that in the world of perfect capital markets, bank lending decisions are independent of banks' capital structure, since the bank will always be able to find investors willing to fund viable lending opportunities; the level of bank capital is irrelevant to lending and also to the monetary policy transmission mechanism Hubbard, Kuttner, and Palia (2006). This theory or logic of Modigliani and Miller existed as bank's lending depended on its capital structure as well as on lending opportunities and market interest rates. When equity is sufficiently low, because of loan losses or some other adverse shock, the bank will reduce lending because the capital requirement is not currently binding. The model shows that a low capitalized bank may optimally forgo profitable lending opportunities now to lower the risk of future capital inadequacy (Chami \& Cosimano, 2001; Meh \& Moran, 2010). Another important attribute of the model is the maturity transformation performed by banks, exposing them to interest rate risk. The result of this is a monetary tightening, by increasing the short term interest rate, lowers bank profits. Unless the bank can decrease dividends substantially, this will resist over time or cover bank capital given the failure of the Modigliani and Miller logic for less lending. Thus monetary policy affects the supply of bank loans through its effect on bank equity. This dynamic effect of the bank capital channelamplifies the standard interest rate channel of monetary policy.

\subsection{Capital Regulation and Risk taking Behavior of Banks in Nigeria}

Several scholars have documented that the function of bank capital is to reduce bank risk (Adewumi, 1997; Altman, Bharath, \& Saunders, 2002; Berger, Herring, \& Szegö, 1995; Koch \& MacDonald, 2015; Peek \& Rosengren, 1995). A bank that is adequately capitalized can reduce bank risk in the following ways:

i. By providing a cushion to absorb bank losses. In this regard, losses occasioned by bad loans, poor securities investment, criminal and management misjudgment are cushioned which allows the banks to continue in its operations and in the process the said losses are either corrected or recovered. The bank's capital is said to be the last resort against failures. 
ii. By building depositors and general public confidence on the banks institutions and creditors reassurance by adequate capital (Adewumi, 1997).

iii. Adequate capital serves as a regulator of bank's growth. Peek. and Rosengren (1995) found that hundreds of smaller banks with weak capital base went under through mergers because of burgeoning growth in large business loans, which could only be made by banks with stronger or adequate capital base.

iv. The Nigerian banking laws however stipulates that the maximum loan that can be given to a single borrower must not be more than $20 \%$ of the shareholders' fund unimpaired by losses. Also banks that fail to maintain the required minimum capital ratios are prohibited from advertising for or accepting new deposits, granting of credit, making investment and paying cash dividend to shareholders.

Furthermore, it is expedient to state that the bank capital channel plays a critical role in its lending behavior. Banks with higher level of capital are in a better position to absorb shock, losses and repay deposit in a timely manner (Bhatta, 2015). Admati et al. (2010) asserted that the role of bank equity became highly recognized after the 2008 financial crises. The crises have apparently strengthened the fact that highly leveraged banks do not create negative externalities. The works of Peek and Rosengren (1995) and Woo (2003) based in Japan investigated whether negative shocks to capital induced in the above countries banks restricts lending. The studies provided evidence that negative shocks to bank capital leads to significant decline in lending. Similarly, there has been a debate in literature as to whether stifling of bank capital would lead to a contraction of bank loans supply during recession. It was found that during recession, bank loans supply was contracted due to stifling of capital. Using different methodologies, various scholars have shown that loan growth at individual banks were positively related to the initial capital ratio (Bernanke. \& Lown, 1991). Furthermore they argued that capital unconstrained banks could react to negative shocks to capital by increasing deposit taking. When banks are not capital constrained there is an expectation of negative linkage between shocks to capital and deposit taking. On the contrary they document a positive link between shocks to capital and the dynamics of deposit. Berger. and Udell (1994) concluded that expansion of loan was lower for less capitalized banks but do not detect the sensitivity of loan expansion to capital ratio during recession and favors the hypothesis that capital crunch adversely affects loans expansion during the 1990s.

\subsection{Empirical Evidence}

It has been well documented that undercapitalized banks reduce their lending more than well-capitalized ones. Using cross-sectional bank level data, Bernanke. and Lown (1991) showed that loan growth between the second quarter of 1990 and the first quarter of 1991 was positively correlated with banks' capital ratios at the beginning of the period. Berger. and Udell (1994) argue that higher capital requirements encouraged banks to reduce lending to the most risky categories of borrowers. They showed that US banks reduced their commercial loans and increased their holdings of Treasuries in the early 1990s. However, the reduction in borrowers' risk profile can increase banks' financial soundness. Small businesses heavily depend on banks for credit, since it may be difficult for them to find alternative sources of funding (Brewer, Genay, Jackson, \& Worthington, 1996; Cole, Wolken, \& Woodburn, 1996).

Lower lending to these borrowers can slow down economic growth as shown by Hancock and Wilcox (1998) in their study on U.S. for the 1989-1992 periods. Peek and Rosengren (2000) considered the Japanese banking crisis as an exogenous loan supply shock and found that it is linked to construction activity in U.S. commercial real estate markets, thereby affecting economic activity in the U.S. Woo (2003) studied the credit slowdown in Japan in 1997 and concluded that the pervasive shortage of bank capital was the reason behind it. Using data for 107 countries, Barth et al. (2006) for instance, documented that while banks facing more stringent capital regulations have fewer nonperforming loans, the link between capital stringency and banking crises is not robust. Using data from Italian banks in 1992-2001, Gambacorta and Mistrulli (2004) showed that well capitalized banks can better absorb temporary financial difficulties on the part of their borrowers and preserve long term lending relationships. Better capitalized banks can also better shield their lending from monetary shocks as they have easier access to non insured funding. Indeed, loan growth of highly leveraged banks is more responsive to monetary policy than the loan growth of well capitalized banks (Kishan \& Opiela, 2000). Thus, the negative impact of higher short term interest rates on credit availability is stronger for banks with lower capital. Albertazzi and Marchetti (2010) used Italian data for 2007-2009 and found evidence of a contraction of credit supply associated with low bank capitalization. Using US data, Kashyap, Stein, and Hanson (2010) found a positive relationship between bank leverage and equity risk. De Jonghe (2010) measured banks' systemic risk exposures using extreme value theory. The result showed that higher capital reduces banks' exposure to systemic risk. Demirgüç-Kunt and Detragiache (2011) who employed data for over 3000 banks in 86 countries, reported that capital regulation is not robustly associated with bank risk measured by individual bank Z-scores. All studies referred to above suggest that higher capital makes the provision of credit more stable and robust even in economic downturns. More capital also allows banks to better withstand financial and real shocks. Bank capital increases the capacity to raise non insured debt and thus banks' ability to limit the effect of a drop in deposits on lending. Using the Capital Asset Pricing Model (CAPM) framework, Miles, Jing, and Gilberto (2012) estimated the relationship between leverage and equity beta. The study reports that higher capital reduces the chance of banking crises. Small firms become more credit constrained when banks are under pressure to satisfy capital requirements. This has been documented by Popov and Udell (2012). They studied the sensitivity of credit supply to banks' financial conditions in 16 emerging European countries before and during the recent financial crisis and results suggested that the effect of positive and negative shocks to a bank on its lending is greater for riskier firms and firms with fewer tangible assets. Another type of lending those banks cut when being capital constrained is loans to the real estate sector. De Haan and Klomp (2012) used data on 200 banks in 21 OECD countries and applied factor analysis on 25 indicators of banking risk, the study reported that capital regulation reduces capital and asset risk of banks. Based on a 40 years data from the United States, Baker and Wurgler (2013) confirmed that better capitalized banks have both lower systematic risk (beta) and lower idiosyncratic risk. Another line of research examined the impact of capital requirements on bank risk taking. Kapan and Minoiu (2013) employed a sample of more than 800 banks from 55 
countries during 2006-2010 and the result showed that bank capital played a cushioning role. Better capitalized banks (with lower leverage ratio) that when exposed to the financial market shocks decreased their supply of loans less than other banks.

Using data for German banks covering the period 1965-2009, Buch and Prieto (2014) found that a long run increase in bank capital of one percent increased bank loans by 0.23\%. Interestingly, bank loans decreased with bank capital only when the capital to asset ratio is above $33 \%$. Also, during the recent financial crisis, banks with strong balance sheets were better able to maintain their lending. Recent study by Martynova (2015) showed that higher bank capital increases the franchise value of core banking activities; this allows banks to attract new funds that can be used for investment in risky market based activities. De Haan. and Klomp (2015) found similar results for a sample of emerging and developing countries. However, some other studies in this line of research, report that there is not a strong relationship between capital requirements and bank risk. Using Spanish Credit Register data on all monthly information requests lodged by banks on borrowers, Jiménez, Ongena, Peydró, and Saurina (2012) showed that a one percent increase in the interest rate decreases loans granted by less capitalized banks by 3.9 percent more than loans granted by well capitalized banks. As a result, higher bank capital is important in reducing banks' financial fragility as well as their ability to survive financial crises. (Beltratti \& Stulz, 2012; Diamond. \& Rajan, 2001). In a sample of banks from advanced and emerging economies, the latter study found that higher pre crisis capital improved bank performance during the 2008 crisis. Similarly, Berger and Bouwman (2013) showed that higher capital in US banks enabled them to improve their market shares during banking crises, and these banks are generally able to maintain their improved shares afterwards (although the results are less robust for the 2008 crisis). Since higher capital reduces bank risk and creates a buffer against losses, it makes funding with non insured debt less information sensitive. (Admati et al., 2010). This decreases the possibility of bank runs enhancing financial stability (Admati et al., 2010; Diamond \& Rajan, 2000). However, studies that focus on banks in advanced economies during the 2008 crisis alone often come to different conclusions. Thus, using OECD data (Huang \& Ratnovski, 2009) found no relationship between pre crisis bank capital and performance during the crisis. For their sample of European banks, Camara, Laetitia, and Amine (2010) reported that well capitalized banks took more risk before the 2008 crisis. Using a sample of 36 major global banks, the IMF's GFSR 2009 found that banks that received government support during the crisis had statistically higher capital metrics before the crisis. The BCBS [Basel Committee on Banking Supervision] (1999) surveyed the evidence for the response of banks in the G10 countries to the introduction of the 1988 capital requirements, concluding that bank capital pressures during cyclical downturns in the US and Japan may have limited bank lending in those periods and contributed to the economic weakness in some macroeconomic sectors. Using panel data on large US commercial banks between 1989 and 1997, Furfine (2000) developed a structural dynamic model. The simulations predicted that a one percentage point increase in risk based capital requirement resulted in 5.5\% reduction in loan growth. Albertazzi and Marchetti (2010) using Italian data after the Lehman collapse, documented two percentage points higher contraction of credit supply by less capitalized banks than well capitalized ones. The study also highlighted that borrowers had a limited ability to find substitute funding. Puri, Rocholl, and Steffen (2011) studied the effect of the financial crisis on the lending of German banks. The study concluded that banks hit by the crisis reject $11 \%$ more loan applications than non affected banks.

Several studies estimated the effect of increased capital requirement on bank lending using UK data for the 1990s-2000s. Thus, Francis and Osborne (2012) modeled the targeted capital ratios; based on those numbers they computed capital shortfalls which are further used to explain credit growth. The authors found that a one percentage point increase in capital requirements would reduce lending in 2002 by $1.2 \%$. Using data for the UK banks subject to time varying capital requirements in 1998-2007, Aiyar, Charles, and Tomasz (2014b) exploited a single equation approach and showed that a one percentage point rise in capital requirement reduces credit growth by 6.5-7.2 percentage points. Aiyar., Charles, and Tomasz (2014c) used a Bayesian hierarchical approach to estimate panel VAR models and found that an increase in capital requirements by one percentage point reduces the growth rate in real lending by 4.6 percentage points. Bridges et al. (2014) focusing on the effect of capital requirement on sectoral lending, provided an estimate for the reduction in total lending of $3.5 \%$ in response to a one percentage point increase in capital requirement. Aiyar, Charles, John, Yevgeniya, and Tomasz (2014a) using data of 1999-2006 found that higher capital requirements reduce cross border lending as a one percentage point increase in capital requirements is associated with a reduction in the growth rate of cross border credit of 5.5 percentage points.

Another UK study by Noss and Toffano (2014) estimated how an increase in macroprudential capital requirements might affect banks' lending in the face of a credit boom. They provided an upper bound estimate of $4.5 \%$ reduction in lending associated with a one percentage point increase in risk weighted capital requirement. Following the approach of Francis and Osborne (2012) and using the data from 15 countries, BIS MAG (Macroeconomic Assessment Group) (2010) estimated that a one percentage point increase in capital requirement causes a decline of $1.4 \%$ in the volume of lending.

Brun et al. (2013) estimated the macroeconomic effect of the transition from Basel I to Basel II based regulation in France. The study showed that a two percentage points increase in capital requirements led to an increase in aggregate corporate lending by $1.5 \%$, a rise in aggregate investment by $0.5 \%$ and creation or preservation of 235,000 jobs. Thus, most empirical evidence suggested that increase in capital requirements by one percentage point force banks to cut their total lending in the short run by $1.2-4.5 \%$ or reduced credit growth by $1.2-4.6$ percentage points.

Mesonnier and Monks (2014) used the recapitalization exercise of 2011-2012 by the European Banking Authority (EBA). The EBA announcement was unexpected and required banks to have higher capital ratios than foreseen in transition to Basel III. Exploiting data for 250 large banks in the euro area, they found that forcing a banking group to increase its Core Tier 1 ratio by one percentage point was associated with a reduction in this group's credit growth by 1.2 percentage points. Similarly, Bridges et al. (2014) reported that UK banks faced with a one percentage point increase in capital requirements reduced commercial real estate loan growth by 8 percentage points within one year after the change in capital regulation. 


\section{Methodology}

\subsection{Data}

The data used for this study was secondary in nature and a time series data obtained from the publications of the Central Bank of Nigeria statistical bulletin 2019 and Nigeria stock exchange fact sheet. Data were collected for the period of 1986 to 2019 on bank credits to the private sector (CPS) and credit to small and medium enterprises (CSM) as proxies for banks lending behavior.

\subsection{Estimation Techniques}

The study used the descriptive statistic and econometric in its analysis. The descriptive statistic analysis was carried out to ascertain the behavior of the variables of study utilizing such measures as the mean, median, standard deviations, skewness and kurtosis, and the Jarque-Bera statistic. Furthermore, the study used graphical analytical techniques such as line graphs, histogram and stacked bar charts, among others while for the econometric analysis the unit root test was used to investigate the stationarity of the variables as a non stationarity could lead to spurious regression results. However, the ARDL model was be adopted as the estimation technique of the study, while the Granger Causality Test was also applied in checking the underlying structure of the dynamic relationship between the variables.

\subsection{Model Specification}

Following the previous works of Pesaran and Shin (1996); Canta (2011) and Aliero, Abdullahi, and Adamu (2013) the study assumed that the Basel Capital Channel and Lending Behavior of Banking Institutions in Nigeria: An Empirical investigation can be modeled using two sets of models as follows:

$$
C P S=f(B A S i, B A S i i, B A S i i i)
$$

To have the estimable version of above equation, Equation 1 can be rewritten to have:

$$
C P S=\beta_{0}+\beta_{1} B A S i+\beta_{2} B A S i i+\beta_{3} B A S i i i+U \quad \text { Eq. (2) }
$$

Where: CPS $=$ Credit to Private Sector

$$
\begin{aligned}
\text { BASi } & =\text { Basel I Capital }(\text { Tier } 1+\text { Tier } 2) . \\
\text { BASii } & =\text { Basel II Capital (Total capital requirement) } . \\
\text { BASiii } & =\text { Basel III Capital Conservation Buffer }(\mathrm{CSB})+\text { Counter-Cyclical Buffer }(\mathrm{CCB}) \\
\mathrm{U} & =\text { Error term }
\end{aligned}
$$

$$
C S M=f(B A S i, B A S i i, B A S i i i)
$$

We can rewrite Equation 3 to have:

$$
C S M=\beta_{0}+\beta_{1} B A S i+\beta_{2} B A S i i+\beta_{3} B A S i i i+U \quad \text { Eq. (4) }
$$

Where:

$\mathrm{CSM}=$ Credit to Small and Medium Enterprises

BASi = Basel I Capital (Tier 1 + Tier 2).

BASii = Basel II Capital (Total capital requirement).

BASiii = Basel III Capital Conservation Buffer (CSB) + Counter-Cyclical Buffer (CCB).

$\mathrm{U}=$ Error term

\section{Data Analysis}

4.1. Trends of Basel Capital and Macroeconomic Variables
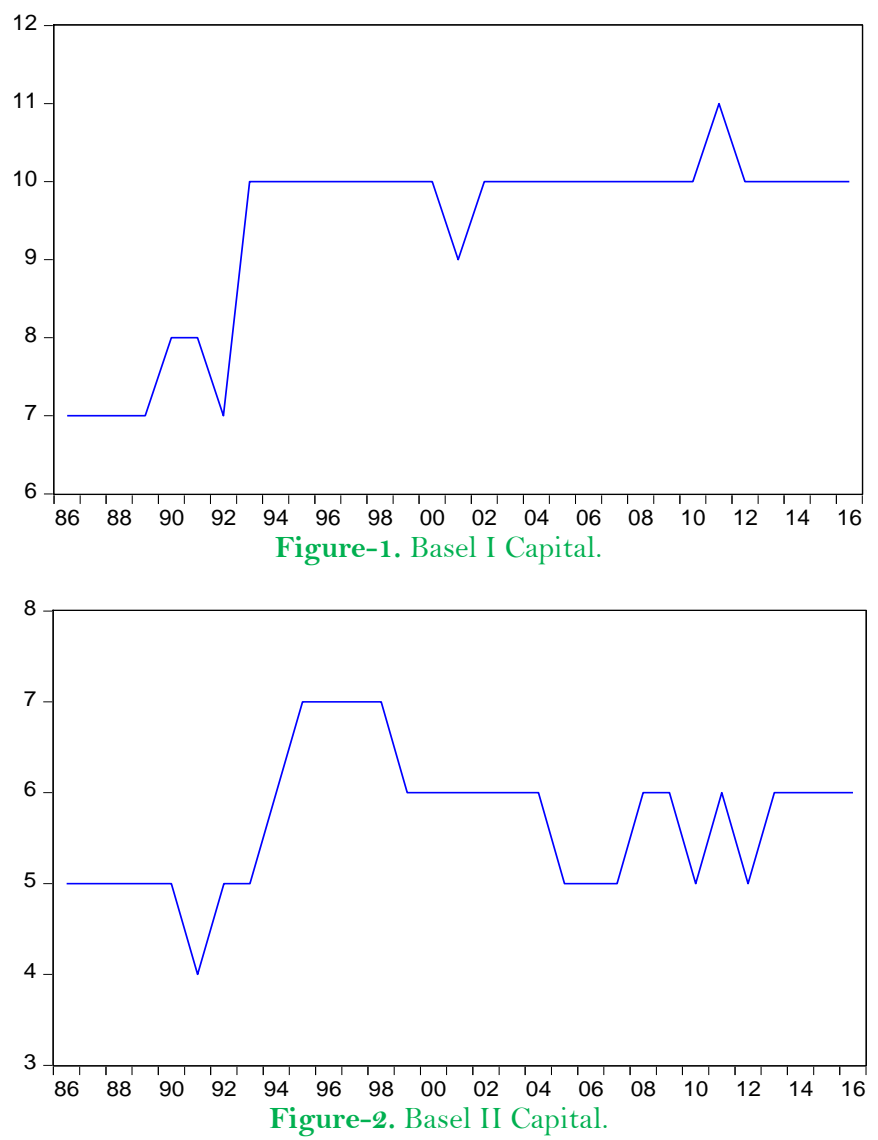


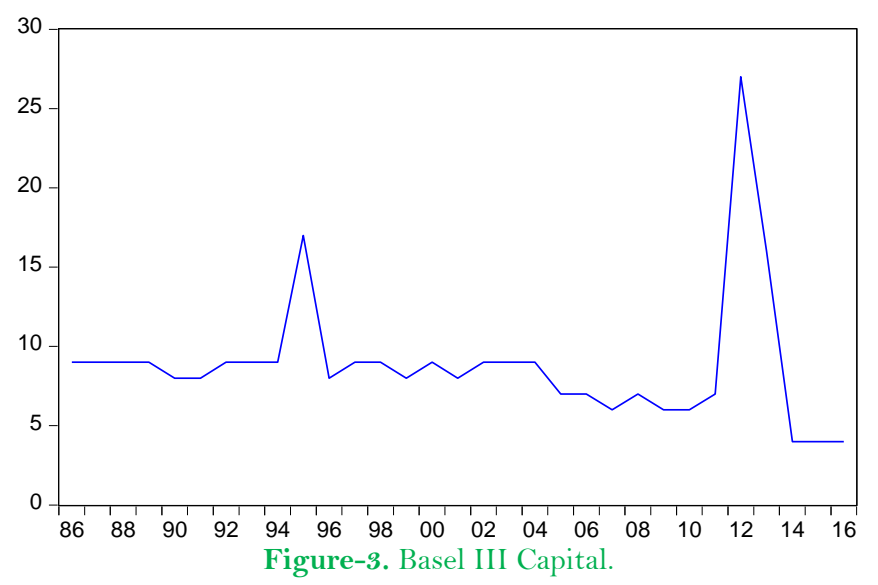

The Basel Capital trend analyses are found in Figure 1, 2 and 3 above. Basel I capital ratios in Nigeria showed a rising trend in terms of credit risk provisions. Basel II ratios showed a constant trend without any improvement in the absorption of credit, market and operational risks. However, Basel III capital showed a declining trend, explained by declining provisions in conservation and pro-cyclical buffers.
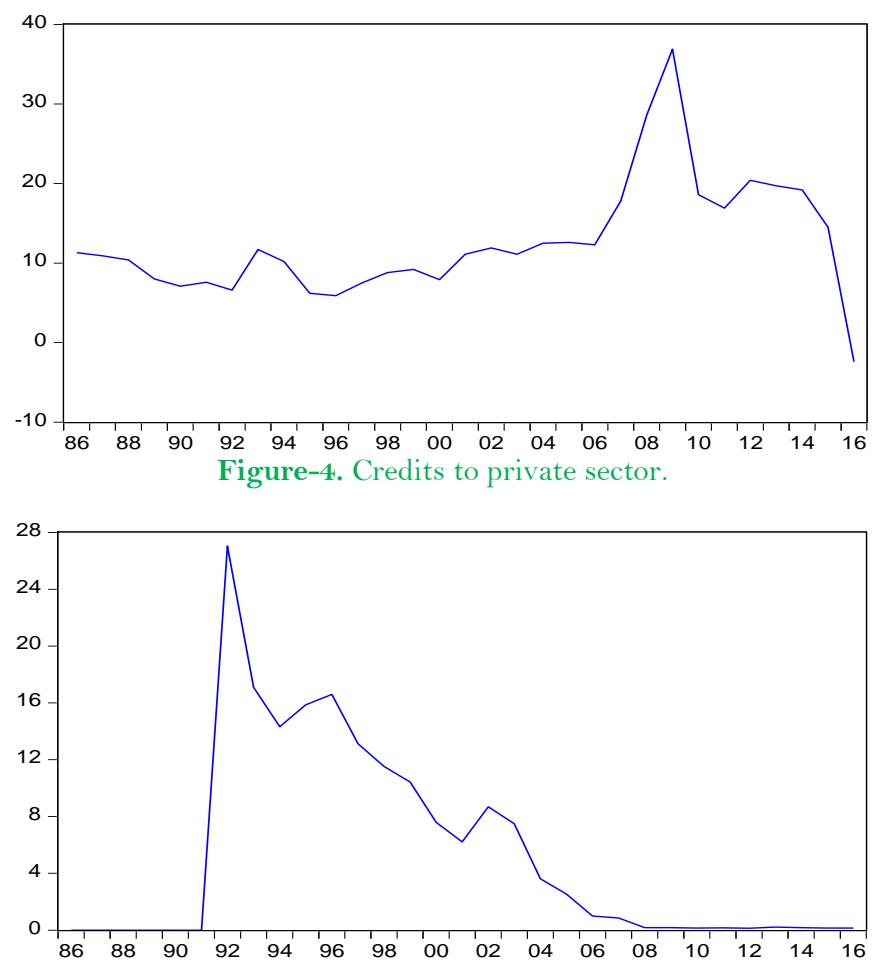

Figure-5. Credits to small and medium enterprises.

The trends in bank lending behaviors are summarized in Figure 4 and 5 above. The growth in credit to the private sector showed a rising trend with a remarkable peak in 2008, and trough in 2019. Growth of credit to the SMEs sector showed a remarkable downward trend.

\subsection{Descriptive Statistic}

Table-1. Descriptive statistics.

\begin{tabular}{c|c|c|c|c|c}
\hline Variable & CPS & SME & BASE I & BASE II & BASE III \\
\hline Mean & 12.61290 & 5.336129 & 9.387097 & 5.677419 & 8.870968 \\
\hline Median & 11.10000 & 0.850000 & 10.00000 & 6.000000 & 9.000000 \\
\hline Maximum & 36.90000 & 27.04000 & 11.00000 & 7.000000 & 27.00000 \\
\hline Minimum & -2.400000 & 0.000000 & 7.000000 & 4.000000 & 4.000000 \\
\hline Std. Dev. & 7.314084 & 7.155078 & 1.202149 & 0.747757 & 4.318502 \\
\hline Skewness & 1.301863 & 1.268652 & -1.251100 & 0.103223 & 2.697124 \\
\hline Kurtosis & 5.815111 & 3.864529 & 2.962837 & 2.515799 & 11.57840 \\
\hline Jarque-Bera & 18.99297 & 9.281046 & 8.088911 & 0.357883 & 132.6373 \\
\hline Probability & 0.000075 & 0.009653 & 0.017519 & 0.836155 & 0.000000 \\
\hline Observations & 31 & 31 & 31 & 31 & 31 \\
\hline Note:
\end{tabular}

Note:
CPS $\quad$ Credit to Private Sector.

$\mathrm{SME}=$ Small and Medium Enterprises.

$B A S_{I}=$ Basel I Capital (Tier $1+$ Tier 2$)$

$B A S_{I J}=$ Basel II Capital (Total Minimum Capital)

$B A S_{I I I}=$ Basel III Capital (Conservation Buffer (CSB) + Counter-Cyclical Buffer (CCB)).

The results in Table 1 showed mean values of $9.38 \%, 5.68 \%$ and $8.87 \%$ for Basel I, II, and III for the period under study. The gap between the maximum and minimum values is widest in terms of Basel III (27.0 and 4.0). In addition, the provisions under Basel III offer wider absolute variations with a standard deviation of $4.32 \%$. With a mean average of $12.61 \%$ and $5.34 \%$, it is observed that growth in credit to the private sector and SMEs experienced 
the widest swing with a standard deviation of $7.31 \%$ and $7.16 \%$. The distributions of Basel capital and variables of lending bahaviors are not normal with evident of asymmetrical skewness, leptokurtic kurtosis and flat tails. This is confirmed by the Jarque-Bera statistics and associated probabilities.

\subsection{Econometric Analyses \\ 4.3.1. Unit Root Test}

Table-2. Unit root test for Basel measures.

\begin{tabular}{c|c|c|c}
\multicolumn{4}{c}{ Table-2. Unit root test for Basel measures. } \\
\hline Variable & D(BASi) & D(BASii) & D(BASiii) \\
\hline ADF Statistics & -7.587722 & -6.903685 & -6.284499 \\
\hline $1 \%$ & -3.679322 & -3.679322 & -3.679322 \\
\hline $5 \%$ & -2.967767 & -2.967767 & -2.967767 \\
\hline $10 \%$ & -2.622989 & -2.622989 & -2.622989 \\
\hline Probability & 0.0000 & 0.0000 & 0.0000 \\
\hline
\end{tabular}

The study conducted stationary test for the Basel capital channel variables using the Augmented Dickey Fuller (ADF) unit root test. The results are summarized and presented in Table 2 for each of the variables studied. From the above table it is obvious that the three variables were non stationary at levels but appears stationary at first difference. Hence, the series are all integrated of order 1(1). This is evidenced by the fact that the absolute values of the ADF test statistics are all greater than the MacKinnon critical values at 1\%, $5 \%$, and $10 \%$ level significance and thus the respective null hypotheses of non-stationary are rejected, implying the absence of unit root among the variables.

Table-3. Unit root test for selected macroeconomic variables in Nigeria.

\begin{tabular}{c|c|c|c|c|c}
\hline Variable & D(CPS) & D(SME) & D(RGDP) & D(FDI 1) & D(FDI 1 1) \\
\hline ADF Statistics & -3.742833 & -6.747184 & -7.494608 & -3.997403 & -3.820481 \\
\hline $1 \%$ & -3.679322 & -3.679322 & -3.679322 & -3.679322 & -3.679322 \\
\hline $5 \%$ & -2.967769 & -2.967767 & -2.967767 & -2.967767 & -2.967767 \\
\hline $10 \%$ & -2.622989 & -2.622989 & -2.622989 & -2.622989 & -2.622989 \\
\hline Probability & 0.0086 & 0.0000 & 0.0000 & 0.0046 & 0.0071 \\
\hline
\end{tabular}

The study conducted stationary test for the selected macroeconomic variables using the Augmented Dickey Fuller (ADF) unit root test. The results are summarized and presented in Table 3 for each of the variables studied. From the above table it is obvious that all the selected macroeconomic variables were non stationary at levels but appears stationary at first difference. Hence, the series are all integrated of order 1(1). This is evidenced by the fact that the absolute values of the ADF test statistics are all greater than the MacKinnon critical values at $1 \%, 5 \%$, and $10 \%$ level significance and thus the respective null hypotheses of non-stationary are rejected, implying the absence of unit root among the variables.

\subsection{Relationship between Basel Capital and Bank Lending Behavior}

Table-4. Autoregressive distributed lag (ARDL) results for Basel capital and CPS.

\begin{tabular}{l|c|c|c|c}
\hline Variable & Coefficient & Std. Error & T-Statistic & Prob. $^{*}$ \\
\hline CPS(-1) & 0.478330 & 0.351294 & 1.361621 & 0.2006 \\
\hline CPS(-2) & -0.417282 & 0.492191 & -0.847805 & 0.4146 \\
\hline CPS(-3) & -0.036859 & 0.509674 & -0.072319 & 0.9436 \\
\hline CPS(-4) & 0.898983 & 0.473097 & 1.900208 & 0.0839 \\
\hline BASi & 0.104338 & 1.488245 & 0.070108 & 0.9454 \\
\hline BASii & 3.548238 & 1.753683 & 2.023306 & 0.0080 \\
\hline BASii(-1) & 3.609792 & 3.081279 & 1.171524 & 0.0261 \\
\hline BASii(-2) & -6.290792 & 1.931521 & -3.256912 & 0.0076 \\
\hline BASii(-3) & 0.618392 & 2.611562 & 0.236790 & 0.8172 \\
\hline BASii(-4) & 3.136528 & 2.311307 & 1.357036 & 0.2020 \\
\hline BASiii & -0.984963 & 0.339355 & -2.902456 & 0.0144 \\
\hline BASiii(-1) & -0.787566 & 0.456055 & -1.726910 & 0.1121 \\
\hline BASiii(-2) & -0.442777 & 0.253565 & -1.746204 & 0.1086 \\
\hline BASiii(-3) & -0.724596 & 0.311443 & -2.326576 & 0.0401 \\
\hline BASiii(-4) & -1.217085 & 0.304761 & -3.993579 & 0.0021 \\
\hline C & 11.60274 & 12.00310 & 0.966646 & 0.3545 \\
\hline R-squared & 0.893054 & Mean dependent var & 12.97778 \\
\hline Adjusted R-squared & 0.747219 & S.D. dependent var & 7.771859 \\
\hline S.E. of regression & 3.907481 & Akaike info criterion & 5.850907 \\
\hline Sum squared resid & 167.9525 & Schwarz criterion & 6.618810 \\
\hline Log likelihood & -62.98724 & Hannan-Quinn criter. & 6.079245 \\
\hline F-statistic & 6.123729 & Durbin-Watson stat & 1.889550 \\
\hline Prob(F-statistic) & 0.002206 & & & \\
\hline Note: *p-values and any subsequent tests do not account for model selection & & \\
\hline
\end{tabular}

Note: *p-values and any subsequent tests do not account for model selection. 
The ARDL results in Table 4 above captured model 1 of this study. Both the global statistic and the diagnostic test indicated that the utility, forecasting and predictive power of the model as specified was very high. We can thus rely on the relative results to make inferences on the relationship between the variables under study. A cursory look at Table 4 above showed that Basel I capital (BASi) is positively related to growth in credit to the private sector (CPS) at a coefficient of 0.1043 but statistically insignificant at $5 \%$ level of significance at a probability of 0.9454. This means that 1.1 increments in the provision of Basel I capital will lead to 12.1043 increases in CPS. On the other hand, Basel II capital (BASii) related positively with the growth in credit to the private sector though not significant in the current period at $5 \%$ level. This is demonstrated with the coefficient of 3.5482 at a probability of 0.0080 . Though this is significant at $10 \%$, but not accepted as our significance level. However, it turned negative and statistically significant at 5\% with a coefficient of -6.2908 and probability of 0.0076 when lagged in the second period. Also Basel III capital (BASiii) is statistically significant at $5 \%$ level but with a negative probability and coefficient of (-0.9850 and 0.0144) for the current period, (-0.7246 and 0.0401) for the third period and -1.2171 and 0.0021 for the fourth period respectively when lagged. In addition, the coefficient of determination $\left(\mathrm{R}^{2}\right)$ of 0.89 in Table 4 shows that 89 percent of variation in growth of credit to the private sector is explained by changes in Basel capital. This relationship is significant at the $5 \%$ level since the F-statistic of 6.1237 falls outside the critical region of \pm 0.0022 . Hence we reject the $\mathrm{HO} 1$, and accept the alternate.

\begin{tabular}{|c|c|c|c|}
\hline Null Hypothesis & Obs & F-Statistic & Prob. \\
\hline BASi does not Granger Cause CPS & 29 & 0.28778 & 0.7525 \\
\hline \multicolumn{2}{|l|}{ CPS does not Granger Cause BAsi } & 0.43405 & 0.6529 \\
\hline BASii does not Granger Cause CPS & 29 & 1.06422 & 0.0007 \\
\hline \multicolumn{2}{|l|}{ CPS does not Granger Cause BASii } & 0.21290 & 0.8097 \\
\hline BASiii does not Granger Cause CPS & 29 & 0.10279 & 0.9027 \\
\hline \multicolumn{2}{|l|}{ CPS does not Granger Cause BASiii } & 0.12265 & 0.8851 \\
\hline BASii does not Granger Cause BASi & 29 & 0.57833 & 0.5685 \\
\hline \multicolumn{2}{|l|}{ BASi does not Granger Cause BASii } & 0.93912 & 0.4049 \\
\hline BASiii does not Granger Cause BASi & 29 & 0.08027 & 0.9231 \\
\hline \multicolumn{2}{|l|}{ BASi does not Granger Cause BASiii } & 0.70820 & 0.5025 \\
\hline BASiii does not Granger Cause BASii & 29 & 0.86320 & 0.4345 \\
\hline \multicolumn{2}{|l|}{ BASii does not Granger Cause BASiii } & 1.05049 & 0.3653 \\
\hline
\end{tabular}

The results in Table 5 shows that a F-statistics of 0.2878 and 0.1028 at $5 \%$ level of significance, for Basel I (BASi) and (0.2878 and 0.1028) for Basel III (BASiii) capital. Similarly they recorded a probability of 0.7525 and 0.9027 for both Basel I and III. This is indication that Basel I and Basel III capital does not cause growth in credit to the private sector (CPS) as there probability is above the stipulated $5 \%$ significance level. However, it was also observed from results that causality runs unidirectional from Basel II capital (BASii) to growth in credit to the private sector as shown by the F-statistic and probability of 1.0642 and 0.0007 respectively. This implied that an enhancement in Basel II capital (BASii) will trigger up growth in credit to private sector. Further, it suggested that as banks continue to comply with the provision of Basel II capital, growth in credit to the private sector will be raised as well.

Table-6. Autoregressive distributed lag results for basel capital and credit to SMEs.

\begin{tabular}{l|c|c|c|c}
\hline Variable & Coefficient & Std. Error & t-Statistic & Prob.* \\
\hline SME & 0.943866 & 0.168145 & 5.613400 & 0.0000 \\
\hline BASi & -4.604238 & 1.572343 & -2.928266 & 0.0076 \\
\hline BASi(-1) & 3.358290 & 1.605479 & 2.091768 & 0.0477 \\
\hline BASii & 2.321630 & 1.728992 & 1.342765 & 0.0192 \\
\hline BASii(-1) & -3.440260 & 1.627584 & -2.113722 & 0.0456 \\
\hline BASiii & -0.068078 & 0.206255 & -0.330067 & 0.7443 \\
\hline C & 19.31019 & 9.335211 & 2.068533 & 0.0500 \\
\hline R-squared & 0.682227 & Mean dependent var & 5.514000 \\
\hline Adjusted R-squared & 0.599330 & S.D. dependent var & 7.207350 \\
\hline S.E. of regression & 4.562145 & Akaike info criterion & 6.074426 \\
\hline Sum squared resid & 478.7029 & Schwarz criterion & 6.401373 \\
\hline Log likelihood & -84.11640 & Hannan-Quinn criter. & 6.179019 \\
\hline F-statistic & 8.229790 & Durbin-Watson stat & 1.963761 \\
\hline Prob(F-statistic) & 0.000080 & & \\
Note: ${ }^{*}$ p-values and any subsequent tests do not account for model selection.
\end{tabular}

The ARDL results in Table 6 above, the global statistics and the diagnostic test (DWT) indicated that the utility, forecasting and predictive power of the model as specified was at 0.68 percent. Based on the ARDL results, we can rely on the relative and global statistics results to make inferences on the relationship between the variables under study. Taking a keen look at Table 6 it shows that Basel I capital (BASi) is negatively related and statistically significant to growth in credits to SMEs at a coefficient of 4.6042 and probability of 0.0076 . Furthermore, Basel I lagged in period 1 with a coefficient and probability of 3.3583 and 0.0477 is an indication that there is a positive and significant relationship between Basel I capital and growth in credit to SMEs. On the other hand, Basel II capital (BASii) relates positively but statistically significant at $5 \%$ level. This is confirmed by the Basel II coefficient of 2.3216 and probability of 0.0192 . However, Basel II capital lagged in period 1 turned a negative relationship with a coefficient of -3.4402 but significant with a probability of 0.0456 . This means that there is an inverse relationship between Basel II capital and growth in credit to SMEs. Basel III capital (BASiii) records a beta coefficient of -0.0681 and probability of 0.7443 . Going by this, it means that there is a negative 
relationship between Basel III capital and growth in credit to SMEs which is statistically insignificant at $5 \%$ level. In addition, the coefficient of determination $\left(\mathrm{R}^{2}\right)$ of 0.68 in Table 6 shows that 68 percent of variation in growth of credit to the private sector is explained by changes in Basel capital. This relationship is significant at the $5 \%$ level since the F-statistic of 8.2298 falls outside the critical region of 0.0001 . Hence we reject the $\mathrm{HO} 2$, and accept the alternate.

Table-7. Pairwise granger causality tests.

\begin{tabular}{l|c|c|c}
\hline Null Hypothesis: & Obs & F-Statistic & Prob. \\
\hline BASi does not Granger Cause SME & 29 & 0.85541 & 0.4377 \\
\hline SME does not Granger Cause BASi & 29 & 9.09658 & 0.0011 \\
\hline BASii does not Granger Cause SME & 1.46560 & 0.0050 \\
\hline SME does not Granger Cause BASii & 29 & 3.04631 & 0.0062 \\
\hline BASiii does not Granger Cause SME & 29 & 0.04181 & 0.9591 \\
\hline SME does not Granger Cause BASiii & 0.13677 & 0.8728 \\
\hline BASii does not Granger Cause BASi & 29 & 0.57833 & 0.5685 \\
\hline BASi does not Granger Cause BASii & 0.08027 & 0.9231 \\
\hline BASiii does not Granger Cause BASi & 29 & 0.70820 & 0.5025 \\
\hline BASi does not Granger Cause BASiii & 0.86320 & 0.4345 \\
\hline BASiii does not Granger Cause BASii & 1.05049 & 0.3653 \\
\hline BASii does not Granger Cause BASiii
\end{tabular}

The results in Table 7 shows that at $5 \%$ level of significance causality does not flow from Basel I capital (BASi) to growth in SMEs, this is confirmed by the F-statistics and probability of (0.8554 and 0.4377). But F-statistics and probability shows that causality runs unidirectional from SMEs to Basel I and this is significant at $5 \%$. The Fstatistics (1.4656 and 3.0463) and probability (0.0050 and 0.0062) for Basel II capital (BASii) shows that there exist a bi-directional causality between Basel II and SMEs but this is significant at 10\%, while for Basel III capital (BASiii), the F-statistics of 0.0418 and 0.1368 and the probability of 0.9591 and 0.8728 records that there is no causality between Basel III capital (BASiii) and credit to SMEs. Therefore, the hypothesis of there is no causality is rejected in place of the alternate.

\subsection{Discussion of Findings}

The empirical findings for the study support the theory of bank capital channel that postulate that monetary policy actions influence bank lending behavior, through its impact on bank equity capital. These monetary policy actions can lead to a change in the financial position of the banking sector, thereby changing the preferences of its shareholder (Markovic, 2006). When bank equity capital is sufficiently low, because of loan losses or some other adverse shocks, the bank will reduce lending because of the capital requirement and the cost of issuing new equity. Even when the capital requirement is not currently binding, the model showed that a low capitalized bank may optimally forgo profitable lending opportunities now to lower the risk of future capital inadequacy. Conversely, the empirical results for Nigeria contradicted the Modigliani-Miller irrelevance theory that argued that in the world of perfect capital markets, bank lending decisions are independent of banks institution capital structure, since the bank will always be able to find investors willing to fund viable lending opportunities; the level of bank capital is irrelevant to lending and also to the monetary policy transmission mechanism (Hubbard et al., 2006). This theory or logic of Modigliani and Miller existed as bank's lending depended on its capital structure as well as on lending opportunities and market interest rates. When equity is sufficiently low, because of loan losses or some other adverse shock, the bank will reduce lending because of the capital requirement is not currently binding, the model showed that a low capitalized bank may optimally forgo profitable lending opportunities now to lower the risk of future capital inadequacy (Chami \& Cosimano, 2001; Meh \& Moran, 2010). Previous studies provided evidence on the positive relationship between Bank capital and lending behavior and because the studies were all in advanced economies, it was essential to study whether the same principles would hold given the dynamics of emerging market economies of which Nigeria is one. Empirically, our findings agreed with the works of Berger et al. (1995); Peek and Rosengren (1995); Adewumi (1997); Woo (2003), Albertazzi and Marchetti (2010); Buch and Prieto (2014); Koch and MacDonald (2015); Woo (2003), Albertazzi and Marchetti (2010); Klaus and Philipp (2013) and Jose, Santiago, Ana, and Camilo (2017) in which they opined that under capitalized banks reduced their lending more than the well capitalized and therefore the well capitalized positively influences lending behavior in Nigeria. However, this position was contradicted by the works of Kapan and Minoiu (2013) who argued that better capitalized banks with lower leverage ratio are exposed to financial market shocks decreased their supply of loans less than other banks.

\section{Conclusions}

Based on the findings of the study, we conclude that in Nigeria the theory of bank capital channel which postulates that monetary policy actions influence bank lending behavior, through its impact on bank equity capital is supported. This conclusive position is based on the analysis of the relationship of the variables modeled in the study which showed that Basel capital influences growth in credit to the private sector (CPS) and growth in credit to small and medium enterprises (SMEs). Based on the conclusion, the study therefore recommend as follows:

i. The Central Bank of Nigeria should focus adequate attention in ensuring macroeconomic and monetary stability to enable not only banking business but other businesses to strive in the country/economy.

ii. The monetary authority as a prudential regulator should monitor the banks compliance to the provisions of the Basel capital accords.

iii. Banks should maintain both conservation buffer $(\mathrm{CSB})$ and counter-cyclical buffer $(\mathrm{CCB})$ with the view to absorbing emerging shocks from loan losses. 


\section{References}

Adewumi, W. (1997). The 500 million minimum paid-up capital for banks. The Nigerian Banker, 1(1), 25-29.

Admati, A. R., DeMarzo, P. M., Hellwig, M. F., \& Pfleiderer, P. C. (2010). Fallacies, irrelevant facts and myths in the discussion of capital regulation: Why bank equity is not expensive. Stanford GSB Research Paper No. 2065.

Aiyar, S., Charles, C., John, H., Yevgeniya, K., \& Tomasz, W. (2014a). The international transmission of bank capital requirements: Evidence from the United Kingdom. Bank of England Working Paper No 497.

Aiyar, S., Charles, C., \& Tomasz, W. (2014b). Does macroprudential leak? Evidence from a UK policy experiment. Journal of Money, Credit and Banking, 46(4), 181-214.

Aiyar., S., Charles, C., \& Tomasz, W. (2014c). How does credit supply respond to monetary policy and bank minimum capital requirements? Bank of England Working Paper No 508.

Albertazzi, U., \& Marchetti, J. D. (2010). Credit supply, flight to quality and ever greening: An analysis of bank-firm relationships after Lehman. Banca d'Italia Working Paper No.756.

Aliero, H. M., Abdullahi, Y. Z., \& Adamu, N. (2013). Private sector credit and economic growth nexus in Nigeria: An ARDL bound approach. Mediterranean Journal of Social Science, 4(1), 83-90.

Altman, E. I., Bharath, S. T., \& Saunders, A. (2002). Credit ratings and the BIS capital adequacy reform agenda. Journal of Banking $\Xi^{2}$ Finance, 26(5), 909-921.Available at: https://doi.org/10.1016/s0378-4266(01)00269-2.

Baker, M., \& Wurgler, J. (2013). Do strict capital requirements raise the cost of capital? Banking regulation and the low risk anomaly. NBER Working Paper No. 19018.

Barth, J. R., Caprio, G., \& Levine, R. (2006). Banking regulation and supervision: What works best? Journal of Financial Intermediation, 13(3), 205-248.

BCBS [Basel Committee on Banking Supervision]. (1999). Capital requirements and bank behavior: The impact of the basel accord. BCBS Working Papers No.1.

Beltratti, A., \& Stulz, R. M. (2012). The credit crisis around the globe: Why did some banks perform better? Journal of Financial Economics, 105(1), 1-17.Available at: https://doi.org/10.1016/j.jfineco.2011.12.005.

Berger, A. N., \& Bouwman, C. H. (2013). How does capital affect bank performance during financial crises? Journal of Financial Economics, 109(1), 146-176.Available at: https://doi.org/10.1016/j.jfineco.2013.02.008.

Berger, A. N., Herring, R. J., \& Szegö, G. P. (1995). The role of capital in financial institutions. Journal of Banking Eீ Finance, 19(3-4), 393430.

Berger., A. N., \& Udell, G. F. (1994). Did risk-based capital allocate bank credit and cause a" credit crunch" in the United States? Journal of Money, Credit and Banking, 26(3), 585-628.Available at: https://doi.org/10.2307/2077994.

Bernanke, B. S., \& Blinder, A. S. (1988). Is it money or credit, or both, or neither. American Economic Review, 78(2), 435-439.

Bernanke., B. S., \& Lown, C. S. (1991). The credit crunch. Brookings Papers on Economic Activity, 22(2), 205-248.

Bhatta, G. (2015). Theoretical paradigm on bank capital regulation and its impact on borrower behaviour. NRB Working Paper No. 30.

BIS MAG (Macroeconomic Assessment Group). (2010). Final Report - Assessing the macroeconomic impact of the transition to stronger capital and liquidity requirements (pp. 7-8). Bank of International Settlemnt, Basel, Switzerland.

Blum, J., \& Hellwig, M. (1995). The macroeconomic implications of capital adequacy requirements for banks. European Economic Reviere, 39(4), 739-749.

Blum., J. (1999). Do capital adequacy requirements reduce risks in Banking? Journal of Banking and Finance, 23(5), 755-771.

Brewer, E., Genay, H., Jackson, W. E., \& Worthington, P. R. (1996). How are small firms financed? Evidence from small business investment companies. Economic Perspectives, 20(3), 2-18.

Bridges, J., David, G., Mette, N., Silvia, P., Amar, R., \& Marco, S. (2014). The impact of capital requirements on bank lending. Bank of England Working Paper No. 486.

Brun, M., Fraisse, H., \& Thesmar, D. (2013). The real effects of bank capital requirements. Economic and Financial Debates, Banque de France, Hec Research Paper Series 988, 3-26.

Buch, C. M., \& Prieto, E. (2014). Do better capitalized banks lend less? Long-run panel evidence from Germany. International Finance, 17(5), $1-23$.

Camara, B., Laetitia, L., \& Amine, T. (2010). Changes in capital and risk: An empirical study of European banks. Working Paper No. 56.

Canta, M. (2011). Macroeconomic effects of banking regulation in emerging markets: The role of countercyclical bank capital requirements. A PhD Thesis Submitted to Department of Economics. McGill University, Montreal.

Chami, R., \& Cosimano, T. (2001). Monetary policy with a touch of Basel. International Monetary Fund Working Paper No. 151.

Cole, R. A., Wolken, J. D., \& Woodburn, L. (1996). Bank and nonbank competition for small business credit: Evidence from the 1987 and 1993 national surveys of small business Finances. Federal Reserve Bulletin, 31(2), 11-18.

De Haan, J., \& Klomp, J. (2012). Banking risk and regulation: Does one size fit all? Journal of Banking \& Finance, 36(12), $3197-3212$. Available at: https://doi.org/10.1016/j.jbankfin.2011.10.006.

De Haan., J., \& Klomp, J. (2015). Bank regulation, the quality of institutions and banking risk in emerging and developing countries: An empirical analysis. Emerging Markets Finance and Trade, 2(2), 8-16.

De Jonghe, O. (2010). Back to the basics in banking? A micro-analysis of banking system stability. Journal of Financial Intermediation, 19(3), 387-417.Available at: https://doi.org/10.1016/j.jfi.2009.04.001.

Demirgüç-Kunt, A., \& Detragiache, E. (2011). Basel core principles and bank soundness: Does compliance matter? Journal of Financial Stability, 7(4), 179-190.Available at: https://doi.org/10.1016/j.jfs.2010.03.003.

Diamond, D. W., \& Rajan, R. G. (2000). A theory of bank capital. Journal of Finance, 55(5), $2431-2465$.

Diamond., D. W., \& Rajan, R. G. (2001). Liquidity risk, liquidity creation, and financial fragility: A theory of banking. Journal of Political Economy, 109(2), 287-327.Available at: https://doi.org/10.1086/319552.

Francis, W. B., \& Osborne, M. (2012). Capital requirements and bank behavior in the UK: Are there lessons for international capital standards? Journal of Banking \& Finance, 36(3), 803-816.Available at: https://doi.org/10.1016/j.jbankfin.2011.09.011

Furfine, C. (2000). Evidence on the response of US banks to changes in capital requirements. BIS Working Papers No 88.

Gambacorta, L., \& Mistrulli, P. E. (2004). Does bank capital affect lending behavior? Journal of Financial Intermediation, 13(4), 436457.Available at: https://doi.org/10.1016/j.jfi.2004.06.001.

Hancock, D., \& Wilcox, J. A. (1998). The “credit crunch" and the availability of credit to small business. Journal of Banking Eீ Finance, 22(68), 983-1014.

Huang, R., \& Ratnovski, L. (2009). Why are Canadian banks more resilient? IMF Working Paper No. 0152.

Hubbard, R. G., Kuttner, K. N., \& Palia, D. N. (2006). Are there bank effects in borrowers 'cost of funds? Evidence from a matched sample of borrowers and bank. Journal of Business, 75(4), 559-581.

Jiménez, G., Ongena, S., Peydró, J.-L., \& Saurina, J. (2012). Credit supply and monetary policy: Identifying the bank balance-sheet channel with loan applications. American Economic Review, 102(5), 2301-2326.Available at: https://doi.org/10.1257/aer.102.5.2301.

Jose, F. I., Santiago, M., Ana, R., \& Camilo, U. (2017). Impact of capital regulation on SMEs credit. BBVA Research Working Paper No. O1, 121

Kapan, T., \& Minoiu, C. (2013). Balance sheet strength and bank lending during the global financial crisis. IMF Working Paper 102.

Kashyap, A., Stein, J., \& Hanson, S. (2010). An analysis of the impact of substantially heightened capital requirements on large financial institutions. Journal of Economic Perspectives, 25(3), 3-28.

Kishan, R. P., \& Opiela, T. P. (2000). Bank size, bank capital and the bank lending channel. Journal of Money, Credit and Banking, 32(2), $121-$ 142.

Klaus, D., \& Philipp, K. (2013). Evaluation of minimum capital requirements for bank loans to SMEs. Discussions Paper No. 22. Duetshe Bundesbank.

Koch, T. W., \& MacDonald, S. S. (2015). Bank management (8th ed., pp. 487-541). Australia: Cengage Learning.

Markovic, B. (2006). Bank capital channels in the monetary transmission mechanism. Bank of England Working Paper No. 313. 
Martynova, N. (2015). Effect of bank capital requirements on economic growth. A Survey DNB Working Paper No 467.

Meh, C. A., \& Moran, K. (2010). The role of bank capital in the propagation of shocks. Journal of Economic Dynamics and Control, 34(3), 555576.Available at: https://doi.org/10.1016/j.jedc.2009.10.009.

Mesonnier, J. S., \& Monks, A. (2014). Did the EBA capital exercise cause a credit crunch in Euro Area? Banque de France Working Paper No. 491.

Miles, D., Jing, Y., \& Gilberto, M. (2012). Optimal bank capital. The Economic Journal, 123(6), 1-37.

Noss, J., \& Toffano, P. (2014). Estimating the impact of changes in bank capital requirements during a credit boom. Bank of England Working Paper No. 494.

Peek, J., \& Rosengren, E. (1995). The capital crunch: Neither a borrower nor a lender be. Journal of Money, Credit and Banking, 27(3), 625638.Available at: https://doi.org/10.2307/2077739.

Peek, J., \& Rosengren, E. S. (2000). Collateral damage: Effects of the Japanese bank crisis on real activity in the United States. American Economic Review, $90(1), 30-45$.

Peek., J., \& Rosengren, E. S. (1995). Bank regulation and the credit crunch. Journal of Banking and Finance, 19(5), 625-638.

Pesaran, H. M., \& Shin, Y. (1996). Autoregressive distributed lag modeling to cointegration analysis department of applied economics, University of Cambridge. DAE Working Paper No. 9514.

Popov, A., \& Udell, G. F. (2012). Cross-border banking, credit access, and the financial crisis. Journal of International Economics, 87(1), 147161.Available at: https://doi.org/10.1016/j.jinteco.2012.01.008.

Puri, M., Rocholl, J., \& Steffen, S. (2011). Global retail lending in the aftermath of the US financial crisis: Distinguishing between supply and demand effects. Journal of Financial Economics, 100(3), 556-578.Available at: https://doi.org/10.1016/j.jfineco.2010.12.001.

Van den Heuvel, S. J. (2007). The welfare cost of bank capital requirements. Wharton Financial Institutions Center Working Paper No. 0719.

Woo, D. (2003). In search of capital crunch: Supply factors behind the credit slowdown in Japan. Journal of Money, Credit and Banking, 35(6), 1019-1038.Available at: https://doi.org/10.1353/mcb.2003.0050. 